\title{
ArcheoSciences
}

Revue d'archéométrie

\section{Gold jewellery of devotional images in Campeche State, Mexico}

Bijoux en or des images de dévotion dans l'état de Campeche, Mexique

\section{Eva Brito and Feliciano Chaire}

\section{(2) OpenEdition \\ 12 Journals}

\section{Electronic version}

URL: https://journals.openedition.org/archeosciences/2406

DOI: 10.4000/archeosciences.2406

ISBN: 978-2-7535-1598-7

ISSN: 2104-3728

\section{Publisher}

Presses universitaires de Rennes

\section{Printed version}

Date of publication: 31 December 2009

ISBN: 978-2-7535-1181-1

ISSN: 1960-1360

\section{Electronic reference}

Eva Brito and Feliciano Chaire, "Gold jewellery of devotional images in Campeche State, Mexico", ArcheoSciences [Online], 33 | 2009, Online since 10 December 2012, connection on 28 January 2022. URL: http://journals.openedition.org/archeosciences/2406 ; DOI: https://doi.org/10.4000/ archeosciences.2406 


\title{
Gold jewellery of devotional images in Campeche State, Mexico
}

\section{Bijoux en or des images de dévotion dans l'état de Campeche, Mexique}

\author{
Eva Brito* and Feliciano ChaIre**
}

\begin{abstract}
The objective of this work is to understand the cultural significance of gold, specifically in the use of jewels for the decoration of devotional sculptures, for a population of Mayan origin that currently lives in the State of Campeche, Mexico. We study three cases of cult images of great reputation among Catholics: one from Campeche City and two others from rural areas. The method mainly consisted in recovering data from historic documents, living testimonies and oral traditions, and carrying out an analysis of religious festivities. The cultural value given to these objects by people makes it necessary to recognize them as Communal Cultural Heritage. Only through joint action and cooperation between Catholic communities, the Mexican Government, Church and society in general, we will be able to guarantee their security and preservation.
\end{abstract}

Résumé : L'objectif de l'étude est de comprendre la signification culturelle de l'or pour la population d'origine Maya qui vit actuellement dans l'état de Campeche, au Mexique, particulièrement en ce qui concerne l'utilisation de bijoux pour la décoration de sculptures de dévotion. Trois images de culte, qui jouissent d'excellente réputation parmi les catholiques, ont été étudiées : une située dans la ville de Campeche et les autres deux dans des villes rurales. La méthode comprend l'étude de documents anciens, la récolte de témoignages et traditions orales en direct et l'analyse des fêtes religieuses. La valeur culturelle que les gens donnent à ces objets exige quils soient reconnus comme un héritage de la communauté culturelle. Seule une action conjointe et la coopération entre les communautés catholiques, le gouvernement mexicain, l'église et la société en général, nous garantira leur sécurité et leur préservation.

Keywords: gold jewels, devotional images, Mayan ethnic groups, popular religiosity, México.

Mots-clés : bijoux en or, images de dévotion, groupes ethniques Maya, religiosité populaire, Mexique.

\section{INTRODUCTION}

The ancient Mayan civilization flourished in south-eastern Mexico, in an area including the current states of Campeche, Yucatán, and Quintana Roo (Yucatan Peninsula), Chiapas and Tabasco, extending to Nicaragua in Central America. It was characterized by a polytheistic religion in which gods were classified according to different categories, such as: the creation of the Universe; stars and planets (e.g. sun, moon, Venus); natural phenomena (e.g. rain, wind, thunder); animals (e.g. jaguar, snake); plants (maize, for example); good and evil; and death. Both historical documentary sources and archaeological evidence prove that gold was considered a very important gift to these deities.

With the Spanish conquest of America during the $16^{\text {th }}$ century, an unknown god and new saints came to these

\footnotetext{
* Instituto Nacional de Antropología e Historia - Centro INAH Estado de México, Avenida José Vicente Villada 103, 105 y 107, Toluca, Estado de México, C.P. 50000. (evalebrito@yahoo.com.mx)

** Archaeologist (Escuela Nacional de Antropología e Historia), independent collaborator - Calle José Loco Adam 11, Fraccionamiento Villamar, Campeche, Cam., México, C.P. 24020. (fchaire@live.com.mx)
} 
lands and a process of syncretism of Mayan and Catholic beliefs was initiated (López, 1994). This phenomenon is visible until today in the living manifestations of regional popular piety. In Campeche State, we can still witness the thousand years old relationship between humans and the sacred, using the precious metal par excellence as a mediator. It is worth mentioning that today, Campeche State has a total population of 754,730 inhabitants and that $13.2 \%$ of it has the native language as the primary one.

Addressing this topic, the objective of the present work is to understand the cultural significance of gold, specifically in the use of jewels for the decoration of devotional sculptures, for the population of Mayan ethnic origin that currently lives in this part of Mexico. We specifically studied the cases of three of the cult images that have the best reputation among Catholics: the Black Christ of the Parish of Saint Roman the Martyr, in Campeche City (the capital of the state); the Immaculate Conception of the Virgin Mary, in the village of Pomuch; and the Lord of Health, in the town of Hecelchakán. The local communities contributed money to buy expensive crowns, necklaces, bracelets, crucifixes, and other golden objects to adorn these sculptures.

Finally, we raise some points of discussion and a conclusion focused on the cultural importance of this type of objects, and the necessity to recognize them as Communal Cultural Heritage.

\section{Method}

The first phase of our study included documentary research in order to collect data on the importance of gold for the ancient Mayan society, consulting the works of J.E. Thompson (1982), M. de la Garza (1990) and M.O. Marion (1994), three prestigious researchers of this area. The archaeological evidence pertaining to this subject was taken from the results published by C. Coggins (1994) and M. Schmidt (1994). We also reviewed chronicles of the history of the Church in colonial times, written by Diego López de Cogolludo $\left(17^{\text {th }}\right.$ century, reprinted 1996), which helped us to select the three cases of cult images for this study.

The fieldwork was the longest and most important part of this investigation, which began after we decided to examine one case from Campeche City and two others from towns located on the side of the road that connects the states of Campeche and Yucatan. It consisted, firstly, in the observation and description of the main features of the sculptures, as well as of the jewellery collection of each of them. Then, we registered the calendar of religious holidays and attended to those considered the most significant. During the festi- vities, we collected information about the traditions transmitted in oral form, and we also obtained testimonies about the meaning of gold for communal members.

We then confronted all the data we collected in order to be able to draw conclusions regarding the current role played by gold jewellery for popular religiosity in the region. Finally, we evaluated this role based on the Unesco definition of culture and cultural heritage.

\section{Aurum: the gifT PaR EXCELlenCe FOR MAYAN DEITIES}

The religious ideas of the ancient Mayans represented the guiding axis of their lives. They conceived a Universe inhabited by invisible deities characterized by a dual personality: fussy and dangerous, but also kind and gentle. Therefore, it was possible for human beings to awake their commiseration, to avoid their attacks and receive their blessings, satisfying their demands with rituals, sacrifices and presents (Garza, 1990; Thompson, 1982).

The main objective of these rituals was to ensure the arrival of the rains in order to guarantee the agricultural cycle, especially of maize, which was the basis of their food and was also considered a holy plant. Representations of the rain god Chac, which we can still see on the facades of the pre-Columbian ceremonial centres along the old Camino Real, express concern over this matter (Marion, 1994). One way to please the sacred beings was offering them gold gifts, which were thrown into the cenotes, the natural water deposits located in the Yucatan Peninsula. The clearest example of this is the Sacred Cenote of Chichen Itza (an ancient city that reached its apogee between the years 800 and 1100 $\mathrm{AD})$, which was used as a great receptacle for this type of artefacts (Coggins, 1994; Schmidt, 1994).

However, the essence of this tradition is not a thing of the past, as current examples are observed in Campeche State. The first one is of a place named Hool, where the devotees ask for favours to the Virgin of Candelaria by throwing golden jewels in a lake beside the village. The second example is that of the small town of Chuiná, in which, during Easter, pilgrims from different locations launch gold jewels into the Laguna de Términos, formed by the salt water of the Gulf of Mexico. At the same time, they pray to Our Lady of Sorrows, which is best known precisely as the Virgin of Chuiná. This practice shows the syncretism of the Mayan and Catholic religions, which undoubtedly agree on the concept of gold as an ideal present for the deities. 


\section{THE JEWELS OF THE LORD}

The town and port of San Francisco de Campeche was established in the year 1540 by the Spanish Captain Francisco de Montejo; in 1776, it received the title of City, and in 1857 it became the capital of Campeche State (Brito, 2007).

Oral tradition holds that during the second half of the $16^{\text {th }}$ century a small chapel was built by local people to implore God to cease the attack of a plague of locusts. They also commissioned an image of Christ to a wealthy merchant and a frequent traveller, named Juan Cano de Coca Gaitan. After he bought the artwork, and during the return trip, a first miracle happened: the ship had a fast and successful travel on a rough sea, and finally a safe arrival to Campeche on September 14 of 1565 . It was since then that the seamen adopted him as their Patron Saint; until today, this representation is the most venerated statue of the Diocese of Campeche, having the title of Patron Saint of all the residents of Campeche (Cahuich and Aguayo 1998) (Fig. 1).

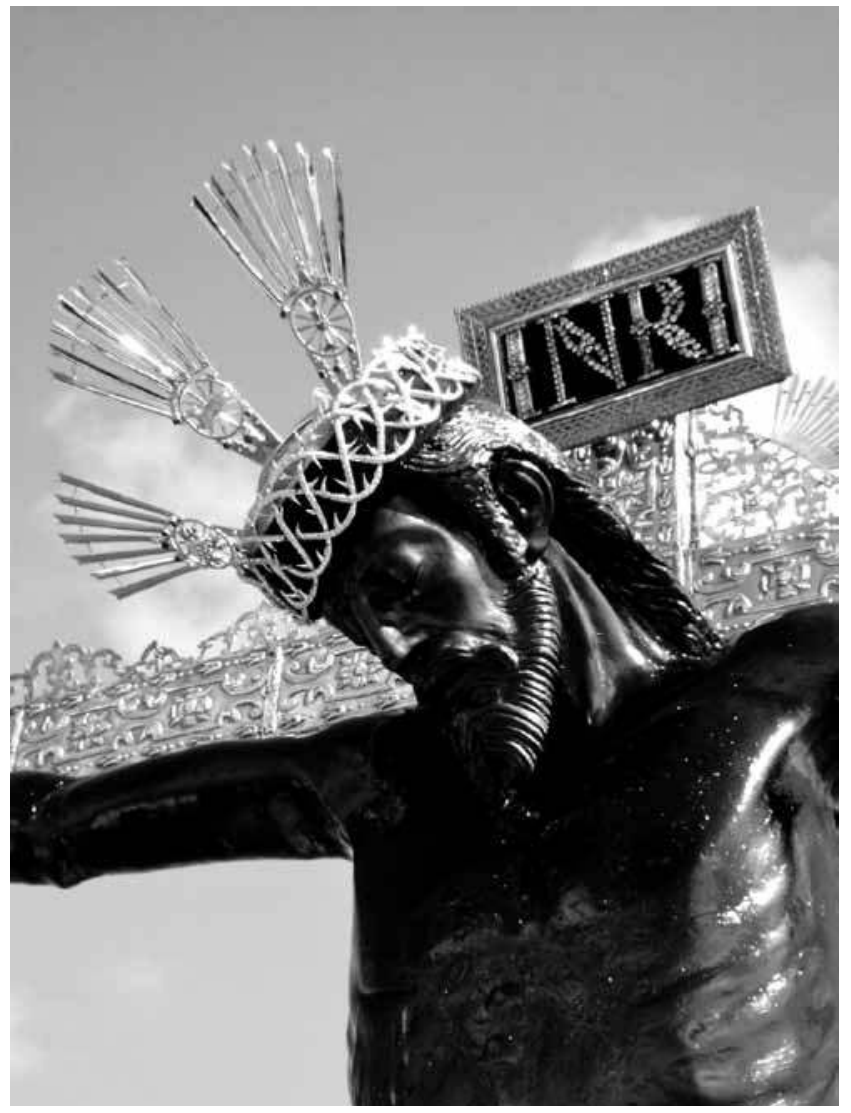

Figure 1: (See colour plate) The "Patron Saint of all the residents of Campeche" of the Diocese of Campeche (Photography: A. Rosado). Figure 1 : (Voir planche couleur) Le "Saint Patron de tous les résidents de Campeche " du Diocèse de Campeche (Photographie : A. Rosado).
The Christ is an anonymous sculpture of unknown origin, probably manufactured with maize pastry, dark brown, and nearly two meters tall. The religious celebration takes place in September, and it has more than four hundred years of annual performance, becoming one of the oldest traditions not only in Campeche State, but in all Mexican territory. During the celebrations, in a similar way to the relationship between the ancient Mayan gods and the vital fluid, the fishermen make a trip along the seashore with the Lord on a boat. This is the occasion when the statue proudly displays its jewellery (Fig. 2).

The sculpture's collection includes gold and silver objects, such as crowns, crucifixes, medals and nails, from the $19^{\text {th }}$ and $20^{\text {th }}$ centuries, donated by the different religious guilds of bakers, carpenters, masons, women and others (Fig. 3). The jewels are housed in the temple, in a safe-deposit box under the supervision of the parish priest, but have no inventory or photographic record. Unfortunately, some of them were lost without any trace.

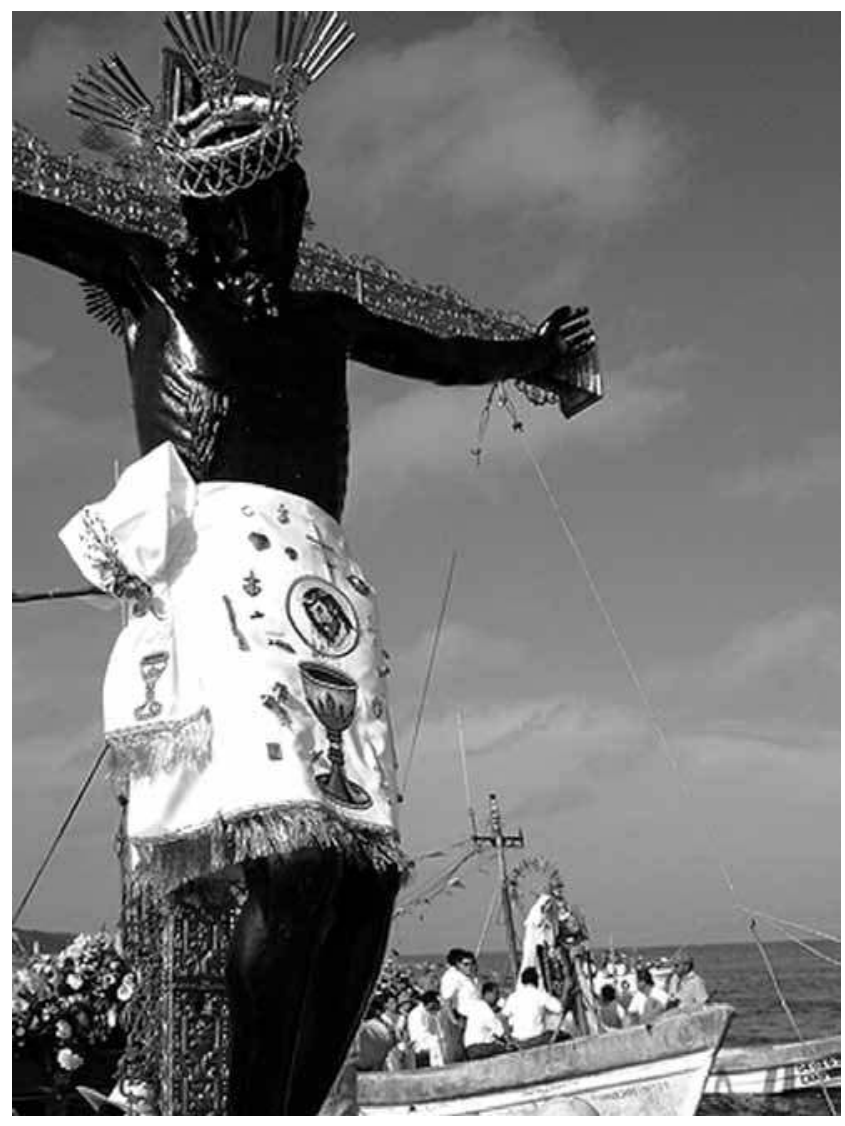

Figure 2: The "Patron Saint of all the residents of Campeche" of the Diocese of Campeche. (Photography: A. Rosado).

Figure 2: Le "Saint Patron de tous les résidents de Campeche " du Diocèse de Campeche. (Photographie: A. Rosado). 


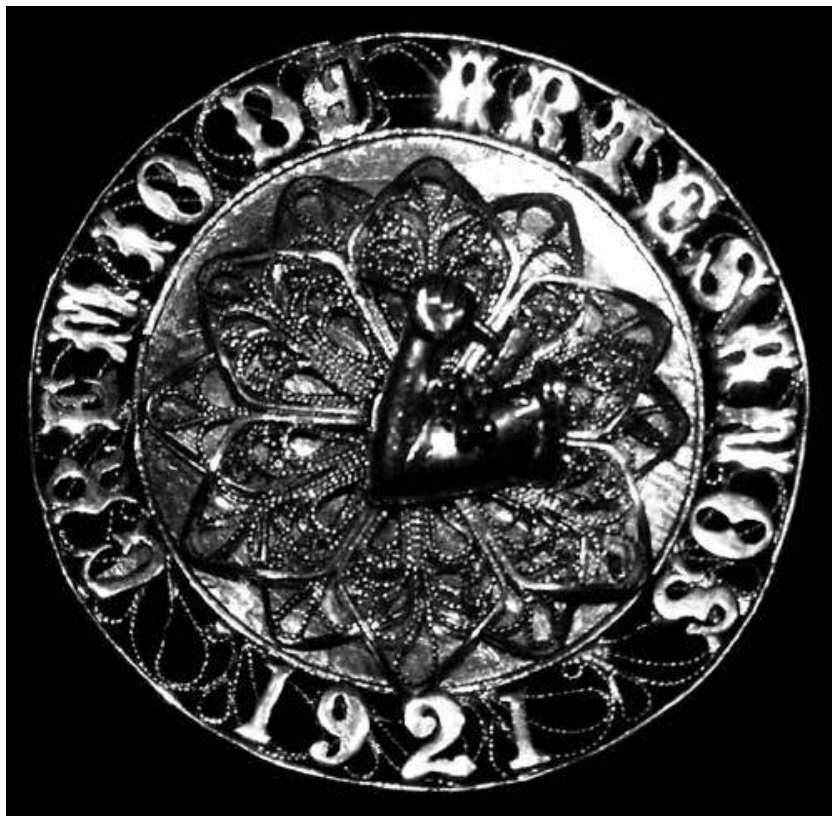

Figure 3: (See colour plate) One of the gold and silver objects from the collection of the Diocese of Campeche. (Photography: A. Rosado). Figure 3: (Voir planche couleur) Un des objets en or et argent de la collection du Diocèse de Campeche. (Photographie: A. Rosado).

At this location, we encountered a problem with the priest, who did not allow us to see the collection, much less analyze it, even though we had a written permission from the bishop. The solution we found was that another church member (a deacon) took photographs of the objects and gave us a copy.

\section{A GOLDEN REWARD FOR CHASTITY}

Pumuch is a small village of Mayan origin, located on one side of the Camino Real, an old road that connects the states of Campeche and Yucatán. The word Pumuch comes from two Mayan terms: poc, meaning 'burn'; and much, meaning 'toad'; therefore, it can be translated as "Place where the toads sunbathe". Today the population consists of 8,180 inhabitants, of whom 3,029 are reported as speakers of Mayan language; their economic base is agriculture (INEGI, 2005).

With the Spanish conquest, the monks of the order of San Francis of Assisi arrived in the mid-16 $6^{\text {th }}$ century to the Yucatan Peninsula with the mission of evangelizing the natives. In Pomuch, they built a rustic wooden chapel with leaf roofs, which years later became a masonry building that was consecrated on January 9,1636 , as indicated by an inscription located on the facade of the temple, to the left of the front door. Currently, the Pomuch Church is under the ecclesiastical jurisdiction of the Parish of Hecelchakán, assigned to the Diocese of Campeche.
The Patron Saint is the Immaculate Conception of the Virgin Mary, represented by a wooden carved and polychrome statue about 1.50 meters tall, with blue dress decorated with small silver stars. It is an anonymous work that seems to correspond to either the second half of the $17^{\text {th }}$ century or the first half of the $18^{\text {th }}$ century. It represents a young woman of regular complexion, in standing position and attitude of prayer (Fig. 4).

According to oral tradition, the chaste Lady appeared miraculously inside a cave next to an underground river; this aspect is again indicative of the relationship between divine beings and water (Ucan, undated). Nowadays she is ensconced in a niche at the centre of the main altar and is the protagonist of three annual events: the Holy Day of the Immaculate Conception of the Virgin Mary on December 8; the Day of the Assumption of the Virgin Mary on August 15; and a festival in April just after Easter, when village women carry the image in a procession (Fig. 5). All this information was provided by Mr. Rafael Pérez Novelo, trader of Pomuch.

The story of her jewels began in 1981, when two sisters of the village, Noemí and Emma Carrillo Briseño, convinced

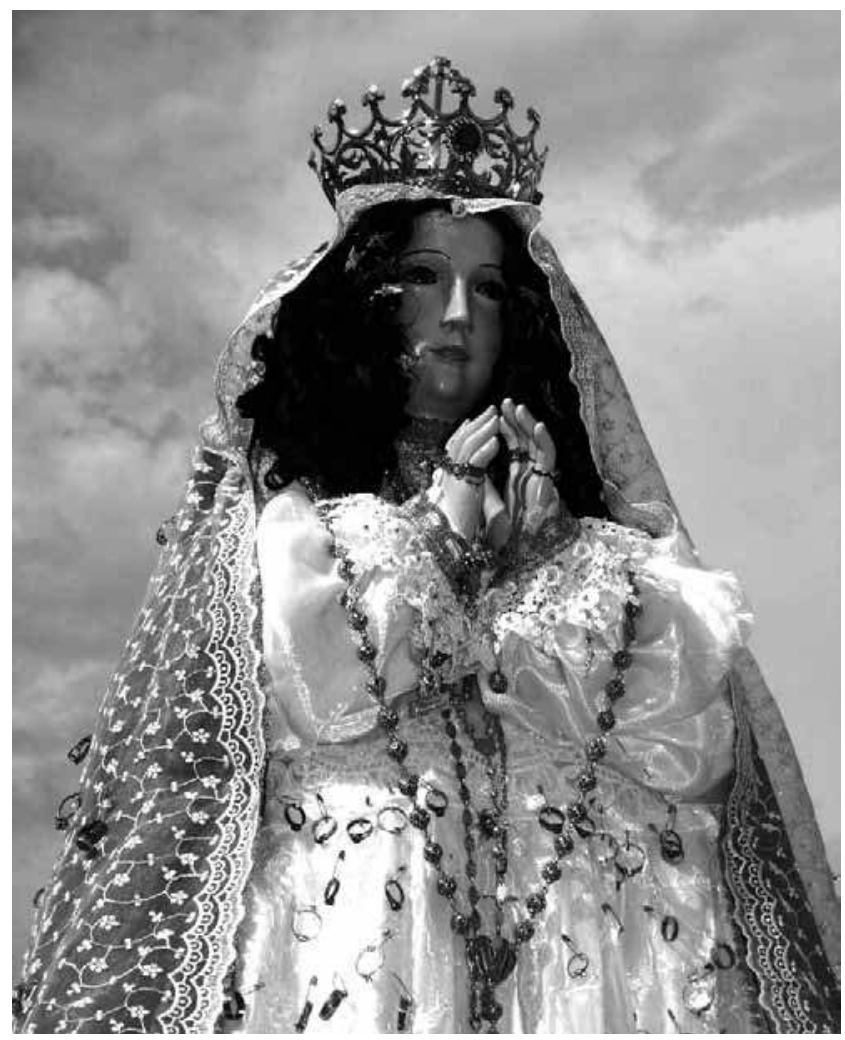

Figure 4: The Immaculate Conception of the Virgin Mary from the Pomuch Church. (Photography: A. Rosado).

Figure 4 : LImmaculé Conception de la Vierge Marie de l'Église de Pomuch. (Photographie: A. Rosado). 


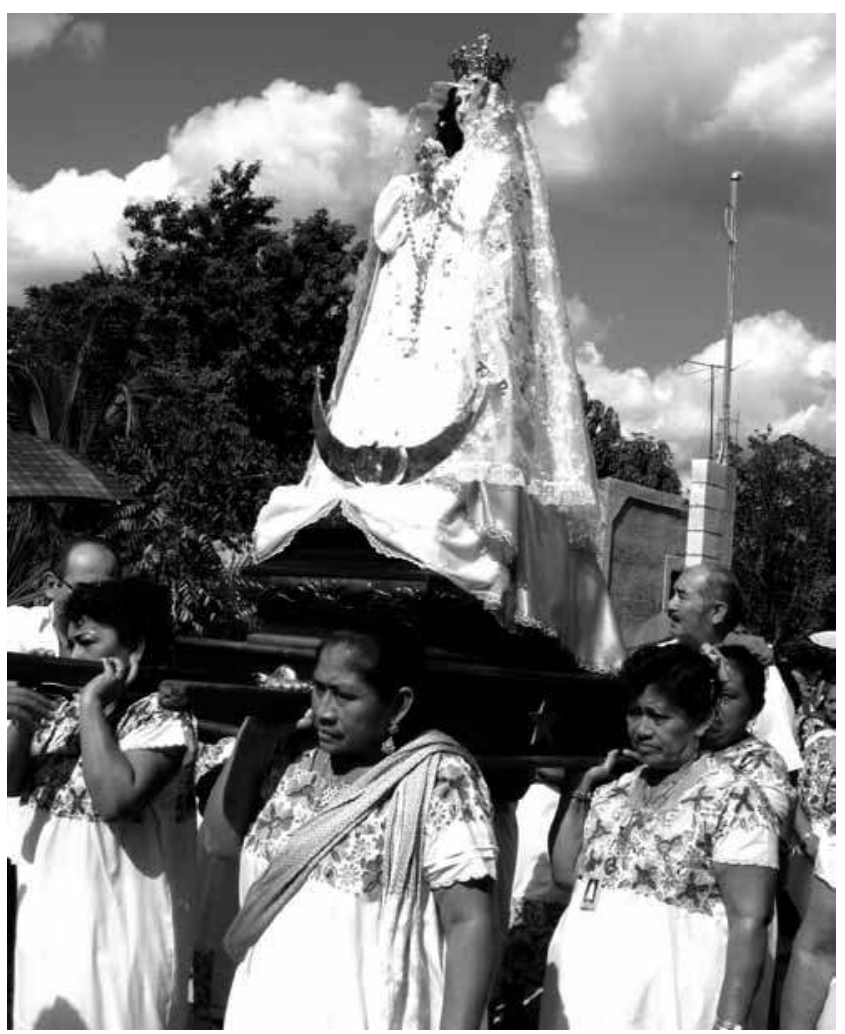

Figure 5: (See colour plate) Easter procession at Pomuch. (Photography: C. Ucan).

Figure 5 : (Voir planche couleur) Procession de Pâques à Pomuch. (Photographie: C. Ucan).

the community that their Queen needed a crown. The Catholics accepted, and the two sisters organized the purchase and all members of the community worked together very hard to collect money. Finally they bought an 18-karat gold crown, weighing 4 kilograms, with stone inlays simulating rubies and brilliants. It cost 140,000 Mexican pesos (about 1,200 US dollars), which is a significant sum, considering the poverty of the peasant population. A few years later, three thieves climbed to the roof of the temple and tried to steal the jewel, but one of them fell and was successfully apprehended by the police, while the other two were able to flee. Due to the fact that the theft was not consummated, the captured offender obtained his freedom.

Today, the chaste Lady wears her crown permanently, together with the other gold pieces that make up its collection (rings, necklaces, medals, crucifixes, earrings and rosaries), all of them donated by local devotees. Other metal jewels (not made of gold) are kept locked in a safe-deposit box in the temple, whose responsibility is with the sacristan. There is no inventory or photographic record, but people affirm that there is no missing jewellery.
The Catholic community of Pomuch provided us with all kinds of facilities to study the sculpture, and allowed us to photograph it. In addition, they also gave us some photographs. Many people tried to help us by providing testimonies and mentioning elements of oral traditions, denoting a surprising openness to people who are not part of the village.

\section{EXCHANGING GOLD FOR RELIEF}

The word Helelchakan comes from the Mayan words helel and chakán, meaning 'rest' and 'savannah', respectively. Therefore, it can be translated as "Savannah for resting". This is a town located on the old Camino Real; it was founded by Mayan Indians before the Spanish arrival. In 1579, the Franciscan monks built in this place a temple and a convent, which worked as a base for the evangelization of neighbouring sites (López de Cogolludo 1996). Nowadays, it has the title of Parish of Hecelchakán, assigned to the Diocese of Campeche. The Patron Saint is San Francis of Assisi, but the most venerated image is a Black Christ, known as the Lord of Health because of its reputation for curing illnesses (Fig. 6).

This is a sculpture of carved wood, dark brown, about 2 meters tall. It is an anonymous work of unknown origin, but because of its similarity to the Christ of Saint Roman, it is considered an artwork of the $16^{\text {th }}$ century. The religious festival in its honour is performed in April, when the statue is taken on a tour around the town, and the guilds and civil authorities organize bullfights, rides, handicraft selling, cooking of regional foods, fireworks, and folk dances.

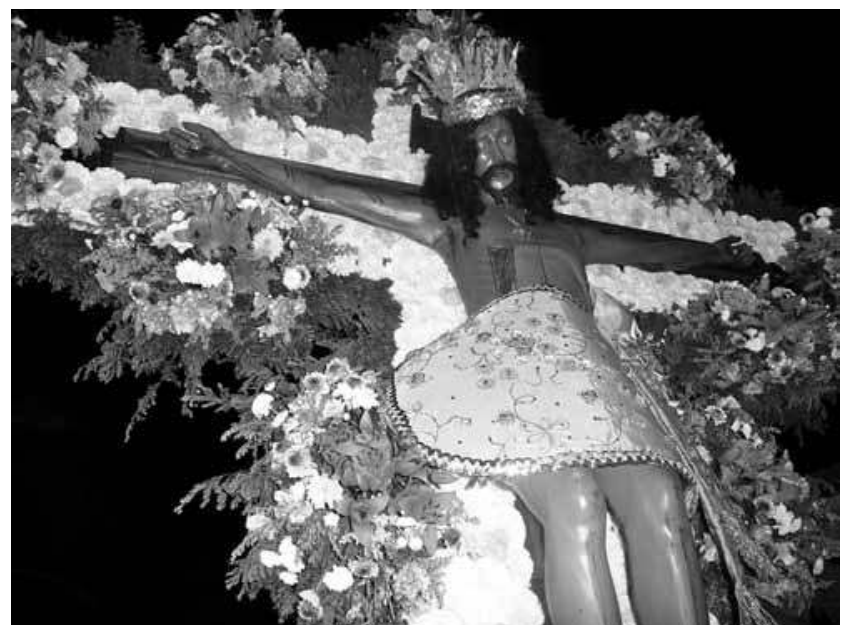

Figure 6: (See colour plate) "Lord of Health", Black Christ of the Diocese of Campeche. (Photography: E. Brito).

Figure 6: (Voir planche couleur) Le "Seigneur de la Santé ", Christ Noir du Diocèse de Campech. (Photographie : E. Brito). 
The Lord has several crucifixes and a crown of gold (part of it), and nails of silver with golden cover, all of them donated by the parishioners asking for health and relief or thanking for it. The jewels are kept by one of the ministers of the Church at his own home. There is no inventory or photographic record, but members of the Catholic community say they have not suffered any loss or theft of jewellery.

At this location, we encountered a similar problem to the one at Saint Roman, because the parish priest and some members of the community did not authorize the minister to show us the collection that is stored in his house, even though we had a written permission of the bishop, nor did we have the possibility to photograph it. The data that we obtained was in oral form, from other members of the Catholic community and priests, and the result of our own personal observations and photographic record during the religious events.

\section{DisCussion AND CONCLUSION}

In addition to the historical significance that gold had for the pre-Columbian civilization, it still maintains to this day an important meaning for the current Mayan population in Campeche State, where it is still possible to observe practices of popular religiosity that recover past cultural elements. Neighbours of the towns of Hool and Chuiná throw jewels into the lake and lagoon similarly to how their ancestors did it in the cenotes.

However, the fieldwork of this study allowed us to conclude that nowadays, people prefer offering more personal items to their statues. For this reason, they donate jewels such as earrings, necklaces, rings, crucifixes and crowns, which come into physical contact with the bodies of their sacred images. If the contact is closer, believers feel they are closer to God and the saints, and thus, they materialize their need to be comforted, healed, forgiven, blessed, but most of all, to be heard praying for the eternal salvation of their souls. In this way, devotees prove their faith to themselves and to the community, repeating the cycle every time that the image is made to carry and show the presents, especially during holy celebrations.

Added to this, as gold has historically represented one of the ideal gifts for the gods, the belief exists that, with a jewel of this material, a saint will be more pleased than with objects of other types of material. If the jewel is finer, the mortal is believed to be closer to heaven.

The fact that we were not allowed to personally examine or photograph the jewellery collections of two of the representations we studied, rather than reflecting a safety concern, indicates that the objects have already been transferred to a sacred level. Moreover, these objects become mediators between God or the represented saints, and the donors, whether individuals or groups (as the religious guilds). Because of this, only their owners and custodians are entitled access to the jewellery.

With this experience, we conclude that these gold pieces go beyond their purely monetary value, and become an essential part of the religious beliefs and rituals. In this regard, the definition given by the United Nations Educational, Scientific and Cultural Organization (Unesco) for cultural heritage of the people states that it includes:

$[\ldots]$ the body of values which give meaning to life. It includes both tangible and intangible works through which the creativity of that people finds expression: languages, rites, beliefs [...] (Unesco, 1982).

Thus, according to this definition, the gold jewels of devotional images need to be recognized as Communal Cultural Heritage. This recognition will generate rights for the owners of the materials, but also an obligation to ensure their safety and preservation. Nevertheless, this commitment must also be assumed by the Mexican government, the Church, religious tourism, and society in general. Only then we will be able to preserve the culture that is producing these assets, in this case, the culture of the population of Mayan origin that currently lives in the State of Campeche, whose wealth is a gift of gold that Mexico offers to the entire world.

\section{Aknowledgements}

Alfonso de Maria y Campos Castelló, Director of Instituto Nacional de Antropología e Historia; Bishop Dr. Ramón Castro Castro and Priest Armando Rosado Cel, of Diocese of Campeche; Lic. Carlos Ucan Yam, Mrs. Emma and Mimi Carrillo Briseño, and Mr. Rafael Pérez Novelo, of the Village of Pomuch.

\section{References}

Brito, E.L., 2007. La Historia de la Catedral (México). Gobierno Constitucional del Estado de Campeche.

Cahuich, G. and Aguayo, M., 1998. La Feria de San Román. Historia de una mentalidad 1505-1997 (México). Secretaría de Cultura y Deporte, Secretaría de Turismo del Gobierno del Estado de Campeche, Instituto de Cultura de Campeche.

Coggins, C.Ch., 1994. El cenote sagrado, Arqueología Mexicana 2(7): 47-49. 
GARZA, M. de La, 1990. El hombre en el pensamiento religioso nábuatl y maya (México). Universidad Nacional Autónoma de México.

INEGI, 2005. II Conteo de Población y Vivienda (México). Instituto Nacional de Estadística y Geografía.

López, A., 1994. El conejo en la cara de la luna (México). Consejo Nacional par la Cultura y las Artes, Instituto Nacional Indigenista.

López de Cogolludo, D., 1996. Historia de Yucatán 1688. Tomo II (Campeche), Heroico Ayuntamiento de Campeche.

Marion, M.O., 1994. Fiestas de los pueblos indígenas. Identidad y ritualidad entre los mayas (México), Secretaría de Desarrollo Social, Instituto Nacional Indigenista.
Schmidt, M., 1994. Chichén Itzá, Arqueología Mexicana 2(7): 38-45.

Thompson, J.E., 1982. Historia y religión de los mayas (México), Siglo XXI Editores, S.A.

Ucan, C.E., undated. Leyendas Purísima Concepción de la Virgen (Campeche).

Unesco. World Conference of Cultural Policies, Mexico City, 26 July -6 August, 1982. 



\section{Authentication: APPLYING EXPERT KNOWLEDGE AUTHENTIFICATION : APPLICATION DES CONNAISSANCES DU SPÉCIALISTE}


